\title{
Can iron work for pigs as a booster?
}

\author{
Olga Urbaniak, Paweł Spyrka, Anna Rząsa
}

\begin{abstract}
Iron deficiency is a common health problem in mammals, especially in growing piglets hence iron administration to suckling piglets is a routine practice in swine production.

A total number of 160 weaners were allotted to two experimental groups according to body weight (I - cachectic underweight piglets; II - piglets with appropriate weaning body weight). Additionally, each group was divided into two subgroups, with iron administered to piglets in subgroups IA and IIA on the first day of the experiment. In order to monitor the weight gains in pigs, they were weighed twice. To estimate the haematological status, blood samples were taken on the weaning day from selected piglets (10 in each subgroup). Haematological analyses were conducted using $\mathrm{Hb}, \mathrm{Ht}, \mathrm{RBC}, \mathrm{MCV}, \mathrm{MCH}, \mathrm{MCHC}$ as early anaemia indicators. Additionally plasma iron (PI) and total iron-binding capacity (TIBC) were assessed as parameters of the actual and potential circulating extracellular iron.

The aim of the study was to investigate the effect of additional postweaning Fe supplementation on production results. A lower concentration of PI was noted in weaker piglets (Group IA and IB). Throughout the experiment higher daily gains were noted in Group II; differences between Group IIA and IA as well as IB were statistically confirmed at $\mathrm{p} \leq 0,01$.

It might be expected that an additional Fe dose applied in weaning piglets can be used as a growth promoter. On the other hand, in case of cachectic animals toxicity of supplemental iron must be taken into consideration.
\end{abstract}

\section{Running title:}

Keywords: iron, piglets, weaners, iron deficiency anaemia

* Correspondence: anna.rzasa@upwr.edu.pl

Department of Immunology, Pathophysiology and Veterinary Preventive Medicine, Wroclaw University of Environmental and Life Sciences, Poland Full list of author information is available at the end of article 


\section{INTRODUCTION}

A marked similarity between porcine and human physiological mechanisms arouses increasing interest in the use of the swine biomedical model in human studies. There is a number of reports on research into the pathogenesis of human cardiovascular diseases, disseminated intravascular coagulation, pathophysiological mechanism of IDA (iron deficiency anaemia) shock, atherosclerosis, diabetes, metabolic disturbances as well as hereditary disorders conducted on the swine model $[1,2,3,4,5,6]$.

Increased productivity raises iron demand in piglets. Physiological anaemia observed in growing pigs whose iron demand has not been satisfied affects economic results. Piglets are born with low iron supplies of $\sim 50 \mathrm{mg}$, which is mostly found in haemoglobin. Rapid growth causes a demand for 50-70 mg in the first weeks of life. Moreover, sows' milk usually provides piglets with iron below their requirements ( 1-2 mg of iron daily) [7, 8, 9]. Since contemporary sows farrow more piglets, which additionally are heavier at weaning, their raise in good health condition becomes challenging $[10,11]$.

A common reason for iron deficiency in pigs is rapid growth (piglets double their body weight during the first 6-8 days), which results in the increase in blood volume and the number of red blood cells. Administration of iron to piglets is a standard practice in swine husbandry to prevent anaemia and improve production results. This practise must be taken before weaning, during the first days of piglets' life $[4,12]$.

An optimal route, dosage, source, timing and method of this microelement [18] administration is a matter of discussion. The efficacy and side effects of different ways of iron supplementation have been well described. The advantages of oral iron supplementation (oral solution or paste form) include no suffering and lower costs. Nevertheless, what is the most important is that absorption is regulated by the intestinal mucosae. The response to oral iron therapy is poor, which may suggest some immaturity in the molecular machinery of duodenal iron absorption [13]. During the suckling period iron uptake via the oral route may be limited even if sufficient sow milk is available and, what is more, calcium contained in milk interferes with intestinal iron absorption [7]. Consequently, intramuscular iron injections during the initial postnatal days have become routine farm practice in anaemia prevention. The most common and effective method of iron supplementation are intramuscular injections of iron dextran [14, 15]. However, this method could be associated with some adverse effects (acute toxicosis, rhabdomyolisis, polymyositis, nerve damage). Certain side effects are noticeable also in the case of oral treatment (water solutions, oral paste), where piglets fed with high iron dosages can show increased susceptibility to bacteria resulting in diarrhea and infections [16]. Excess iron can be lethal as it facilitates the formation of free radicals, which in turn may be involved in enhanced oxidative stress $[13,17]$. Apart from oxidative stress in tissues, excess iron may cause lower feed intake and impairment of essential trace mineral absorption owing to the competition for common intestinal transporters. In order to ensure that a selected therapy has a positive effect on growth performance and production parameters several studies were conducted $[9,12,18,19,20,21,22,23,24,25,26,27$, 28]. Svoboda and Drabek (2004) report that 3-day-old piglets injected with iron showed significant increase in haematological parameters $(\mathrm{Hb}, \mathrm{MCV}$, $\mathrm{MCH}, \mathrm{MCHC}, \mathrm{PI}$ ) on the 21st day of life, whereas piglets from no treatment group developed hypochromic anaemia [29]. In the latter group iron deficiency resulted also in considerably lower body weights on the 21st day of life compared to treated groups. Comparable efficiency of two parenteral routes of iron administration (intramuscular and subcutaneous) was noted as well. The authors suggest that the lack of differences between the intramuscular route (transport via lymph nodes) and subcutaneous route (slower absorption from adipose tissue) could be explained by the small amount of fat in 3-day-old piglets and the proximity to local lymph nodes. In their discussion of another trial conducted by Lipinski et al (2010), the authors highlighted poor response of pigs to oral iron therapy caused by an immature molecular mechanism of iron absorption (low level of duodenal divalent metal transporter 1 and ferroportin; high expression of hepcidin) $[13,30,31,32$, $33,34]$. The necessity of parenteral supplementation in piglets has also been mentioned regarding risks and benefits connected with the efficacy of anaemia treatment but also possible oxidative damage. The same conclusion about the comparison of the administration routes was made during the trial carried out by Chwen et al (2001), where supplementation with oral paste resulted in mild anaemia at 28 days of age [14]. Jolliff and Mahan [8] demonstrated that iron injections of $200 \mathrm{mg}$ at birth depleted at 17 days of age in heavier and fast-growing piglets. The types of iron administration were compared by Pollmann et al (1983) and no difference was found in the $\mathrm{Hb}$ status of pigs when iron dextran and gleptoferron were used [11].

While pre-weaning iron supplementation has become a routine practice, the role of optimized anaemia prevention as a post-weaning health and growth support in piglet rearing seems still underestimated and deserves wider recognition. There is a body of research which underlines the necessity of additional supplementation pointed to by the indicators of iron deficiency occurrence in the post-weaning period [7, $10,36]$. Growth potential in weaned piglets is high, which results in a rapid increase in blood volume and high nutritional iron requirements. Excluding human mistakes during early supplementation, there are several situations when additional iron doses could 
be necessary during the post-weaning period. One of them is stress connected with weaning, which may lead to appetite loss and, as a consequence, poor iron intake from food. Intestinal absorption (duodenal proteins involved in iron transport) can be upsetted within a few weeks after weaning [37]. Another, and the most important, circumstance is physiological potential of high daily gains and inadequate erytropoesis. Poor haematology results can also be caused by diarrhoea prevention using zinc-oxide as a feed additive, whose high doses interfere with the conversion of iron into ferritin [38, 39].

The intensification of pig production necessitates searching for factors enhancing production parameters. As it was presented above, anaemia symptoms quite often appear in piglets after weaning. The aim of this preliminary study was to verify if additional iron supplementation in older, post-weaning piglets is recommendable and what effect it has on production results.

\section{MATERIAL AND METHODS ANIMALS AND EXPERIMENTAL DESIGN}

The experiment was carried out on a production farm, working in an open cycle on one technological group of weaners. A total number of 160 crossbred weaners (Polish Landrasse x Polish Large White) were introduced to a new sector at the age of 28 days. The animals were alloted to 2 groups: Group I cachectic underweight piglets (below $5 \mathrm{~kg}$ ) and Group II - piglets with appropriate weaning body weight (more than $6 \mathrm{~kg}$ ). Each group was subdivided into two subgroups: A and B; the piglets in subgroups A received an additional dose of iron in Ferran $200 \AA$ on the first day of experiment. The piglets were injected intramuscularly at the neck region with $2 \mathrm{ml}$ of iron-dextran preparation. The animals were then subject to routine care and veterinary treatment.

During the 32-day study body weight was measured twice, on the first and last day of the experiment (moving animals to a nursery and fattening sector, at about 28 and 64 days of life). On the first day blood samples were taken (10 samples from each subgroup) from vena cava crianials to perform haematological analysis and estimate Fe concentration and
TIBC. Haematological examination included: heamoglobin concentration $(\mathrm{Hb})$, hematocrit $(\mathrm{Ht})$ red blood cell count (RBC), mean corpuscular volume (MCV), mean corpuscular haemoglobin $(\mathrm{MCH})$ and mean corpuscular haemoglobin concentration (MCHC). Total and differential leukocytes count was also measured. These indices were measured by haematological analyzer Procan PE-6800 (Shenzen Procan Electronics Inc). Iron concentration was determined in plasma by colorimetric method with Chromazurol (commercial packet MAX\&MAT S.A.). Pointe Scientific, Inc. reagents were used for the quantitative estimation of total iron-binding capacity in serum.

All procedures were approved by the II Local Ethics Committee at the University of Environmental and Life Sciences, Wroclaw, Poland (Permission 110/2014).

\section{STATISTICAL ANALYSIS}

Statistical analysis was performed using STATISTICA 12.5 statistical package (Stat.Soft.Inc.). Differences between treatment groups (IA, IB, IIA, IIB) were determined by the post-hoc Duncan test at 0,05 and 0,01 level. Obtained results are presented in tables as the mean and standard deviation (mean $\pm \mathrm{SD}$ ); statistical differences were presented in tables as A,B $\leq 0,01$ and $a, b \leq 0,05$.

\section{RESULTS}

Production results of the experimental animals are presented in Table 1. On the weaning day Group I piglets were lighter than those in Group II, which was statistically confirmed at $p \leq 0,01$, and this tendency continued until the end of the experiment. Group II piglets showed higher daily gains and differences between Group IIA and the whole of Group I were statistically important $(\mathrm{p} \leq 0,01)$. The percentage of losses in Group I was almost 6 times higher in comparison to Group II. 2 times higher percentage of losses in Group IA comparing to Group IB was noted.

As one can note from presented blood results (Table 1), lower Fe concentration in serum derived from cachectic animals (Group IB) was comparable to heavier piglets (Group II A, B). The analysis of total iron-binding protein (TIBC) showed no significant

TABLE 1 Growth performance of treatment groups ; A,B $\leq 0,01 ; a, b \leq 0,05$

\begin{tabular}{c|c|c|c|c|c}
\hline \multirow{2}{*}{\multicolumn{2}{c|}{ Parameter }} & \multicolumn{2}{c|}{ Group I } & \multicolumn{2}{c}{ Group II } \\
\cline { 3 - 6 } \multicolumn{2}{c|}{} & A & B & A & B \\
\hline Body weigth on the & $\mathrm{x}$ & $4.24 \mathrm{~B}$ & $4.25 \mathrm{~B}$ & $6.66 \mathrm{~A}$ & $6.02 \mathrm{~A}$ \\
28th day [kg] & \pm & 0.30 & 0.21 & 0.93 & 0.50 \\
\hline Body weight on the & $\mathrm{x}$ & $23.96 \mathrm{Bb}$ & $24.18 \mathrm{Bb}$ & $34.07 \mathrm{~A}$ & $30.63 \mathrm{a}$ \\
64th day [kg] & \pm & 5.3 & 5.52 & 7.26 & 7.73 \\
\hline \multirow{2}{*}{ Daily gains [g] } & $\mathrm{x}$ & $308.43 \mathrm{~B}$ & $311.60 \mathrm{~B}$ & $431.67 \mathrm{~A}$ & 390.50 \\
& \pm & 82.16 & 85.66 & 105.01 & 116.06 \\
\hline \multirow{2}{*}{ Losses } & No. & 4 & 2 & 0 & 1 \\
& $\%$ & 10 & 5 & 0 & 2.5 \\
\hline
\end{tabular}


TABLE 2 Haematological parameters in experimental animals (28 days of life); a,b $\leq 0,05$

\begin{tabular}{|c|c|c|c|c|c|}
\hline \multirow{2}{*}{\multicolumn{2}{|c|}{ Parameter }} & \multicolumn{2}{|c|}{ Group I } & \multicolumn{2}{|c|}{ Group II } \\
\hline & & \multirow{2}{*}{$\begin{array}{c}\text { A } \\
15.62 \\
3.5 \\
\end{array}$} & \multirow{2}{*}{$\begin{array}{c}\text { B } \\
15.20 \mathrm{a} \\
4.6 \\
\end{array}$} & \multirow{2}{*}{$\begin{array}{c}\text { A } \\
19.44 \mathrm{~b} \\
6.1\end{array}$} & \multirow{2}{*}{$\begin{array}{c}\text { B } \\
19.28 \mathrm{~b} \\
4.1 \\
\end{array}$} \\
\hline $\mathrm{Fe}[\mu \mathrm{mol} / \mathrm{l}]$ & $\begin{array}{l}X \\
\pm\end{array}$ & & & & \\
\hline TIBC $[\mu \mathrm{mol} / \mathrm{l}]$ & $\begin{array}{l}\mathrm{x} \\
\pm\end{array}$ & $\begin{array}{c}42.20 \\
7.8\end{array}$ & $\begin{array}{c}41.20 \\
7.9\end{array}$ & $\begin{array}{c}41.74 \\
10.2\end{array}$ & $\begin{array}{c}45.27 \\
6.8\end{array}$ \\
\hline $\mathrm{RBC}\left[10^{12} / \mathrm{L}\right]$ & $\begin{array}{l}x \\
\pm \\
\end{array}$ & $\begin{array}{l}5.7 \\
0.6 \\
\end{array}$ & $\begin{array}{l}5.5 \\
0.6 \\
\end{array}$ & $\begin{array}{l}5.4 \\
0.7\end{array}$ & $\begin{array}{l}5.9 \\
0.7\end{array}$ \\
\hline HGB [g/L] & $\begin{array}{l}x \\
\pm \\
\end{array}$ & $\begin{array}{c}121 \\
15 \\
\end{array}$ & $\begin{array}{c}110 \\
20 \\
\end{array}$ & $\begin{array}{c}113 \\
19 \\
\end{array}$ & $\begin{array}{c}117 \\
13 \\
\end{array}$ \\
\hline HCT [L/L] & $\begin{array}{l}X \\
\pm\end{array}$ & $\begin{array}{l}0.45 \\
0.06\end{array}$ & $\begin{array}{l}0.43 \\
0.05\end{array}$ & $\begin{array}{l}0.42 \\
0.07\end{array}$ & $\begin{array}{l}0.44 \\
0.04\end{array}$ \\
\hline $\mathrm{MCV}$ [fL] & $\begin{array}{l}x \\
\pm\end{array}$ & $\begin{array}{c}80.8 \\
7.5\end{array}$ & $\begin{array}{c}79.4 \\
5.0\end{array}$ & $\begin{array}{c}79.1 \\
7.6\end{array}$ & $\begin{array}{c}75.2 \\
5.1\end{array}$ \\
\hline MCH [pg] & $\begin{array}{l}x \\
\pm\end{array}$ & $\begin{array}{c}21.5 \\
1.5\end{array}$ & $\begin{array}{c}20.2 \\
3.7\end{array}$ & $\begin{array}{l}21 \\
1.7\end{array}$ & $\begin{array}{c}20.2 \\
1.3\end{array}$ \\
\hline $\mathrm{MCHC}[\mathrm{g} / \mathrm{L}]$ & $\begin{array}{l}x \\
\pm\end{array}$ & $\begin{array}{c}271 \\
9\end{array}$ & $\begin{array}{c}255 \\
45\end{array}$ & $\begin{array}{c}270 \\
3\end{array}$ & $\begin{array}{c}270 \\
6\end{array}$ \\
\hline
\end{tabular}

TABLE 3 Immunological parameters in experimental animals (28 days of life)

\begin{tabular}{|c|c|c|c|c|c|}
\hline \multicolumn{2}{|c|}{ Parameter } & \multicolumn{2}{|c|}{ Group I } & \multicolumn{2}{|c|}{ Group II } \\
\hline WBC $\left[10^{9} / \mathrm{L}\right]$ & $\begin{array}{l}x \\
\pm\end{array}$ & $\begin{array}{c}\mathbf{A} \\
18.2 \\
12.9\end{array}$ & $\begin{array}{c}\text { B } \\
18.7 \\
11.5\end{array}$ & $\begin{array}{c} \\
16.7 \\
4.8\end{array}$ & $\begin{array}{c}\mathbf{A} \\
17.8 \\
9.1\end{array}$ \\
\hline GRAN $\left[10^{9} / \mathrm{L}\right]$ & $\begin{array}{l}x \\
\pm\end{array}$ & $\begin{array}{c}6.06 \\
1.4\end{array}$ & $\begin{array}{c}5.16 \\
2.0\end{array}$ & $\begin{array}{c}4.93 \\
1.6\end{array}$ & $\begin{array}{c}4.21 \\
1.6\end{array}$ \\
\hline LYM [109/L] & $\begin{array}{l}X \\
\pm\end{array}$ & $\begin{array}{c}6.23 \\
1.3\end{array}$ & $\begin{array}{c}6.25 \\
1.8\end{array}$ & $\begin{array}{c}6.65 \\
1.6\end{array}$ & $\begin{array}{c}6.67 \\
1.4\end{array}$ \\
\hline
\end{tabular}

differences between the groups. During haematological analysis no statistically significant differences were observed between the groups (Tables 2 and 3).

\section{DISCUSSION}

In the presented study the lower level of serum iron in piglets was distinctly associated with lower body weight at weaning. Piglets that were iron deficient on the weaning day also had lower body weight at the end of the study. These findings are similar to the observations by other authors that piglets that were iron deficient and anaemic at weaning were lighter than pigs with normal $\mathrm{Hb}$ levels at weaning $[40,41]$. In experimental animals lower serum iron levels in cachectic animals did not interfere with higher TIBC, as it was published previously [7, 42]. Pigs with higher iron serum levels at weaning were heavier and had greater daily gains in comparison to lighter pigs in Group I. Similar studies with another early anaemia indicator $(\mathrm{Hb})$ were conducted by
Gentry [43]. Hb is a blood component, more precisely a protein in red blood cells containing Fe that carries oxygen to tissues. Packed cell volume (Ht) and $\mathrm{Hb}$ both reflect the amount of functioning $\mathrm{Fe}$ in the body and were used for Fe status assessment [8]. It was found that pigs with higher $\mathrm{Hb}$ levels at weaning had greater daily gains and higher feed intake in the post-weaning period. In a study conducted by Haugegaard et al (2008) it was found that $200 \mathrm{mg}$ of iron dextran given to piglets on the 20th day of life resulted in a significantly higher growth rate (around 20 grams per day for the first 15 post-weaning days) [38] and those results are comparable to the current study. Furthermore, those piglets had a significantly higher level of $\mathrm{Hb}(10 \mathrm{~g} / \mathrm{L}$ more on the weaning day). It was assumed that in our study $\mathrm{Ht}$ and $\mathrm{Hb}$ would be much lower around weaning in heavier and fast-growing piglets than in lighter ones, as it was shown by Jolliff and Mahan [8]. All obtained results were slightly below reference ranges for $\mathrm{Hb}$, but differen- 
ces between the groups have not been statistically proved. It may confirm the conclusions presented by Bhattarai et al (2015) as alternative haematological indices may serve as better early anaemia indicators than traditionally used $\mathrm{Hb}$ concentration. Haematological index measuring failure (e.g. RBC, HCT, HB) may be explained by slow erythrocyte turnover rate $(85$ days). No statistical differences have been observed also in leukocyte analysis. However, the results obtained in Group I (A and B) were higher in comparison to the results in Group II what could confirm that immune system stimulation was higher in this group. Iron influence on granulocyte count and function is still being discussed, but it might be associated with changes in apoptotic response, lower oxidative burst and oxidant product synthesis, resulting in increased neutrophil lifespan [7].

Higher percentage of losses noted in Group I could be explained as a result of poorer health state of these animals at weaning. Moreover, it was observed that higher losses occurred in subgroup A (with an additional iron injection at weaning). In this place a damaging role of iron may be discussed. Special redox properties of iron ions are used in many biochemical reactions (DNA, ATP synthesis, oxygen transport, collagen synthesis), but numerous uncontrolled reactions of iron ions with reactive oxygen species (ROS) may cause iron toxicity. It must be emphasized that most mammals have not developed any physiological mechanisms to release iron from the body [44]. Cachectic animals could be more susceptible to peroxidative damage during excess iron supplementation; higher mortality and the lowest daily weight gains observed in group IA could be explained by this In weak piglets decreased feed intake is observed as a consequence of inflammatory processes and infections, and it might predispose pigs to develop anaemia related to iron deficiency [10]. An additional iron dose in such animals may exacerbate clinical symptoms or/and extend the recovery period. Although it was impossible to prove statistically that an additional dose of iron could improve rearing results, the difference of $60 \mathrm{~g} /$ day in daily gains among heavier animals seems to be worth consideration when choosing an optimal care routine on a farm.

\section{CONCLUSIONS}

The collected data seem to confirm the thesis about a delicate balance between possible benefits and risks of iron supplementation - the efficacy of iron supplements in combating anaemia and oxidative damage caused by iron excess $[40,41]$. Well chosen iron supplementation strategy for the post-weaning period may be essential when looking for the best rearing solutions to help farmers produce at optimal level. Iron injections around weaning time may be a good way to improve production parameters. However, before additional Fe supplementation is implemented, clinical examination of animals must be performed. In case of cachectic animals the toxicity of supplemental iron must be taken into particular consideration.

Promising preliminary studies have shown the necessity of in-depth analyses. Further haematological and health status examinations must be conducted in order to propose an optimal iron supplementation scheme for farmed pigs.

\section{Acknowledgements}

The work was supported by NCBR project PBS3/A8/33/2015

\section{Competing interests}

The authors declared no potential conflicts of interest with respect to the research, autorship, and/or publication of this article

\section{Authors' contribution}

Authors contributed to conception and design of the study; contributed to acquisition, analysis and interpretation of data; and drafted the manuscript. All authors critically revised the manuscript, gave final approval, and agreed to be accountable for all aspects of the work in ensuring that questions relating to the accuracy or integrity of any part of the work are appropriately investigated and resolved

\section{Author details}

Olga Urbaniak, Department of Immunology, Pathophysiology and Veterinary Preventive Medicine, Wroclaw University of Environmental and Life Sciences, Poland

Received: 13 August 2017

Accepted: 05 September 2017

\section{References}

1. DAVIS-JACKSON R, CORREA H, HORSWELL R, SADOWSKA-KORWICKA H, MCDONOUGH K, DEBATA C, GARDNER R, PENN D. Antithrombin III (AT) and recombinant tissue plasminogen activator (R-TPA) used singly and in combination versus supportive care for treatment of endotoxin-induced disseminated intravascular coagulation (DIC) in the neonatal pig. Thromb J 2006; 4 : 7

2. GIRAUD S, FAVREAU F, CHATAURET N, THUILLIER R, MAIGA S, HAUET T. Contribution of Large Pig for Renal Ischemia-Reperfusion and Transplantation Studies: The Preclinical Model. J Biomed Biotechnol. 2011; 53: 21-27.

3. NAIGAMWALLA D, WEBB J, GIGER U. Iron deficiency anemia. Can Vet J. 2012; 53(3): 250-256.

4. PATTERSON J, LEI X, MILLER D. The pig as an experimental model for elucidating the mechanisms governing dietary influence on mineral absorption. Exp Biol Med. 2008; 233 (6): 651-64.

5. PLISZCZAK-KRÓL A, RZASA A, GEMRA M, KRÓL J, ŁUCZAK G, ZYZAK A ZALEWSKI D, IWASZKO-SIMONIK A, GRACZYK S. Age-related changes of platelet and plasma coagulation parameters in young pigs. J Vet Diagn Invest. 28 (5): 561-7.

6. ROBINSON S. Acute vascular rejection/delayed xenograft rejection and consumptive coagulopathy in xenotransplantation. Curr Opin Org Transplant 2003; 8 (1):76-82.

7. BHATTARAI S, NIELSEN J. Early indicators of iron deficiency in large piglets at weaning. J Swine Health Prod. 2015; 23(1):10-17.

8. JOLLIFF J, MAHAN D. Effect of injected and dietary iron in young pigs on blood hematology and postnatal pig growth performance. J Anim Sci. 2011; 89 (12):4068-80.

9. NOVAIS K, SILVA C, SANTOS R, DIAS C, CALLEGARI M, OLIVEIRA E. The effect of supplementing sow and piglet diets with different forms of iron. Revista Brasileira de Zootecnia, 2016; 45 (10): 615-621.

10. KIMBERLY A, FRIENDSHIP R, DEWEY C. Effects of weaning age and dosage of supplemented iron on the hemoglobin concentrations and growth rate of piglets. Swine Health and Production 1997; 5(4): 135-138.

11. POLLMANN D, SMITH J, STEVENSON J, SCHONEWEIS D, HINES R. Comparison of gleptosil with iron dextran for anemia prevention in young pigs. J Anim Sci. 1983; 56: 640-644.

12. KEGLEY E, SPEARS J, FLOWERS W, SCHOENHERR. Iron methionine as a source of iron for the neonatal pig. Nut Res. 2002; 22: 1209-1217.

13. LIPIŃSKI P, STARZYŃSKI R,CANONNE-HERGAUX F, TUDEK B, OLIŃSKI R, KOWALCZYK P, DZIAMAN T, THIBAUDEAU O, GRALAK M, SMUDA E, 
WOLIŃSKI J, USIŃSKA A, ZABIELSKI R. Benefits and risks of iron supplementation in anemic neonatal pigs. Am J Patho. 2010; 177 (3):1233-43.

14. CHWEN L, HENG L, LEE T, KONG M, YOON C. The effects of iron supplementation in preweaning piglets. Mal J Nutr. 2001; 7(1\&2) : 41-49

15. LOH T, LEONG K, TOO H, MAH C, CHOO P. The effects of iron supplementation in preweaning piglets. Malays J Nutr. 2001; 7(1):41-9.

16. CHEN Q LE G, SHI Y, ZHANG S, JIN X. Effect of iron supplementation on intestinal function and oxidative stress in piglets with induced colitis. Anim Sci 2007; 16: 205-213.

17. IMLAY J, LINN S. Dna damage and oxygen radical toxicity. Science; 1988 240 (4857):1302-9.

18. ANTONIDES A, VAN LAARHOVEN S, VAN DER STAAY F, NORDQUIST R. Non-anemic Iron Deficiency from Birth to Weaning Does Not Impair Growth or Memory in Piglets. Front Behav Neurosci. 2016; 10: 112.

19. BEHRENS H, LAUPRECHT E. Studies on body weight development in piglets following intramuscular, subcutaneous and intra-abdominal injections of iron-dextrin-cyanide and Myofer-100. Dtsch Tierarztl Wochenschr 1963; 70: 677-678.

20. BRADY P, KU P, ULLREY D, MILLER E. Evaluation of an Amino Acid-Iron Chelate Hematinic for the Baby Pig. J Anim Sci. 1978; 47: 1135-1140.

21. CHMIELOWSKA - KORZENIOWSKA A, BABICZ M. Changes in chosen blood plasma biochemical parameters in growing pigs. Sci Ann Pol Soc Anim Prod. 2009; 5(1): 9-17

22. FURUGOURI K. Plasma iron and total iron-binding capacity in piglets in anemia and iron administration. J Anim Sci. 1972; 34(3): 421-6.

23. IBEN B. Importance of oral iron supplementation in piglets in the first hours of life. Tierarztl Prax Ausg G Grosstiere Nutztiere. 1998; 26 (1) 36-40.

24. KERNKAMP H, CLAWSON A, FERNEYHOUGH R. Preventing Iron-Deficiency Anemia in Baby pigs. J Anim Sci. 1962; 21: 527-532.

25. PETERS J, MAHAN D. Effects of neonatal iron status, iron injections at birth, and weaning in young pigs from sows fed either organic or inorganic trace minerals. J Anim Sci. 2008; 86: 2261-2269.

26. RINCKER M, HILL G, LINK J, ROWNTREE J. Effects of dietary iron supplementation on growth performance, hematological status, and wholebody mineral concentrations of nursery pigs. J Anim Sci. 2004; 82(11) 3189-97.

27. RZASA A, GRACZYK S, GEMRA M, ŁUCZAK G, ZYZAK A, PLISZCZAK-KRÓL A, IWASZKO-SIMONIUK A, SUCHOLINSKI M, SZYMCZAK W. Iron level and antioxidant status in two-week-old piglets. Bull USAMV 2012; 69.

28. SVOBODA M, BOUDA J, DRABEK J, DOUBEK J. Effect of per os iron lactate supplement on development of haematological profile of piglets in the early postnatal period. Acta Vet Brno 2004; 73: 431-436.

29. SVOBODA M, DRABEK J. Intramuscular versus Subcutaneous Administration of Iron Dextran in Suckling Piglets. Acta Vet Brno 2007; 76 11-15.

30. CHERAYIL B. Iron and immunity: immunological consequences of iron deficiency and overload. Arch Immunol Ther Exp. 2010 ; 58 (6): 407-415

31. D'ANGELO G. Role of hepcidin in the pathophysiology and diagnosis of anemia. Blood Res. 2013; 48 (1): 10-15.

32. GANZ T, NEMETH E. Regulation of iron acquisition and iron distribution in mammals. Biochemica et Biophysis Acta. 2006; 1763: 690-9.

33. GANZ T, NEMETH E. Hepcidin and iron homeostasis. Biochim Biophys Acta 2012; 1823 (9): 1434-1443.

34. HANSEN S, TRAKOOLJUL N, LIU H, MOESER A, SPEARS J. Iron transporters are differentially regulated by dietary iron, and modifications are associated with changes in manganese metabolism in young pigs. J Nutr 2009; 139 (8): 1474-9.

35. RAUW W, KANIS W, NOORDHUIZEN-STASSEN E, GROMMERS F. Undesirable side effects of selection for high production efficiency in farm animals: a review. Live Prod Sci. 1998; 56: 15-33.

36. PETROVIC V, NOVOTNY J, HISIRA V, LINK R, LENG L, KOVAC G. The impact of suckling and post-weaning period on blood chemistry of piglets. Acta Vet Brno 2009; 78: 365-371.

37. NEMETH E, TUTTLE M, POWELSON J, VAUGHN M, DONOVAN A, WARD M, GANZ T, KAPLAN J. Hepcidin regulates cellular iron efflux by binding to ferroportin and inducing its internalization. Sci 2004; 306 2090-2093.

38. HAUGEGAARD J, WACHMANN H, KRISTENSEN P. The effect of supplementing fast-growing, late-weaned piglets twice with $200 \mathrm{mg}$ iron dextran intra-muscularly. Pig J 2008; 61 (6):

39. HENRY P, MILLER E. Iron bioavailability. In: Ammerman CB, Baker DP, Lewis AJ. Bioavailability of Nutrients for Animals. San Diego, California: Academic Press; 1995:175.

40. PERRI A, FRIENDSHIP R, HARDING J, O'SULLIVAN T. An investigation of iron deficiency and anemia in piglets and the effect of iron status at weaning on post-weaning performance. J Swine Health Prod. 2015 24(1):10-20.
41. SCHRAMA J, SCHOUTEN J, SWINKELS J, GENTRY J, DE VRIES REILINGH G, PARMENTIER H.. Effect of hemoglobin status on humoral immune response of weanling pigs differing in coping styles. J Anim Sci. 1997; 75: 2588-2596.

42. EGELI A, FRAMSTAD T, MORBERG H. Clinical, biochemistry, hematology and body weight in piglets. Acta Vet Scand. 1998; 39: 381-393.

43. GENTRY J, SWINKELS J, LINDEMANN M, SCHRAMA J. Effect of hemoglobin and immunization status on energy metabolism of weanling pigs. $J$ Anim Sci. 1997; 75:1032-1040.

44. GODYŃ D, PIESZKA M, LIPIŃSKI P, STARZYŃSKI R Diagnostic of iron deficiency anaemia in piglets in the early postnatal period - a review. Anim Sci Pap Rep. 2016; 34: 307-318. 